\title{
12S rRNA mitochondrial gene as marker to trace Sicilian mono-species dairy products
}

\author{
Lina Tortorici, Rosalia Di Gerlando, Marco Tolone, Salvatore Mastrangelo, \\ Maria Teresa Sardina* \\ Dipartimento Scienze Agrarie e Forestali, Università degli Studi di Palermo, Viale delle Scienze, 90128 Palermo, Italy
}

\section{A R T I C L E I N F O}

\section{Keywords:}

Mitochondrial DNA

Molecular traceability

Dairy products

Autochthonous Sicilian breeds

\begin{abstract}
A B S T R A C T
For a rapid, specific and sensitive identification of cows', ewes' and goats' milk in mono-species Sicilian dairy products, species-specific duplex-PCR protocol was applied. DNA samples from blood and experimental cheeses of Sicilian autochthonous breeds were extracted to amplify the $12 S$ rRNA (and part of $16 S$ rRNA in case of Ovis aries) mitochondrial species-specific gene fragment. The use of species-specific primers for Bos taurus, Capra hircus and Ovis aries species, after electrophoresis on agarose gel, yielded fragments of $256 \mathrm{bp}, 326 \mathrm{bp}$ and $172 \mathrm{bp}$, respectively. Amplification by duplex-PCR of DNA pools from two species showed detection thresholds of $0.1 \%$ of "contaminant" DNA in each mixture. Finally, duplex-PCR assay was applied to experimental cheeses in order to detect the minimum threshold of DNA belonging to one species in cheese made with milk of two species. The results showed a sensitive threshold of $0.1 \%$ of ewes' milk in cows' and goats' cheeses, $0.1 \%$ of cows' milk in ewes' and goats' cheeses, and finally $0.1 \%$ of goats' milk in cows' and ewes' cheeses. The proposed assay represents a rapid and straightforward method of species traceability for the detections of adulteration in Sicilian mono-species dairy products.
\end{abstract}

\section{Introduction}

In general, traceability can be defined as the ability to follow food through all stages of production, processing and distribution (McKean, 2001). Traceability in animal food production is increasingly being demanded by consumers as an essential tool for food safety and quality monitoring. In fact, the ability to discriminate between livestock species or breeds is an element of quality control of animal products (Fernández et al., 2004).

Species identification in dairy products has received great attention in recent years (Mafra et al., 2004) since that authenticity assessment is an important issue regarding the consumers' interests not only for an economic point of view but also for food allergies (De La Fuente and Juárez, 2005). Moreover, species identification in dairy sector is important also to verify compliance with the Production Regulations of many typical dairy products (PDO/PGI) (Bánáti and Herman, 2011; Bottero et al., 2003).

The most common fraud of dairy products is due to the substitution of part of the raw material with another of different origin or with lower cost. Several analytical methods have been applied for species identification in milk and dairy products including immunological (Hurley et al., 2004; López-Calleja et al., 2007a; Xue et al., 2010; Zeleňáková et al., 2008), electrophoretic (Chianese et al., 1990; Mayer, 2005; Molina et al., 1999), chromatographic (Branciari et al., 2000; De Noni et al., 1996; Enne et al., 2005), and spectrometric (Nicolaou et al., 2011). For example, the European Commission Regulation (EC) No 273/2008 laid down detailed rules for the application of EC No 1255/ 1999 as regards methods for the analysis and quality evaluation of milk and milk products. Article 6 of EC No 273/2008 described isoelectrofocusing of $\gamma$-casein as reference method for the detection of cows' milk in cheeses from other dairy species (i.e. ewes', goats', buffalos' milk or mixtures of them), but chemical methods may fail in species identification after excessive proteolysis or heat-induced denaturation of proteins indicator (López-Calleja et al., 2005a).

Nowadays, species-specific PCR has shown to be a reliable method to control the authenticity of dairy products ${ }^{20}$ because a specific target sequence (e.g. $12 S$ rRNA, $16 S$ rRNA, cytochrome $b$, and cox1 gene) can be detected in matrices containing a pool of heterogeneous genomic DNA, such as milk (Galimberti et al., 2013; Mafra et al., 2008). Molecular methods may be the solution as the DNA from somatic cells persists even in the ripened cheese (Plath et al., 1997) and it is also possible to extract amplifiable DNA from pasteurized, filtered, and ultrafiltered milk (Bottero et al., 2002). Among the genetic markers used for species traceability of dairy products, the mitochondrial DNA

\footnotetext{
* Corresponding author.

E-mail address: mariateresa.sardina@unipa.it (M.T. Sardina).
} 
(mtDNA) was mainly studied due to its unique characteristics among species (Bottero et al., 2003; European Commission, 2008; Plath et al., 1997). In fact, using species-specific primers, several authors have used different types of PCR to differentiate cows', goats', and ewes' milk or cheeses (Bottero et al., 2003; Dalmasso et al., 2011; Feligini et al., 2005; Mafra et al., 2004; Mafra et al., 2007; Maudet and Caberlet,2001; Mayer, 2005; López-Calleja et al., 2004; López-Calleja et al., 2005b; López-Calleja et al., 2007b; López-Calleja et al., 2007c).

The Sicilian dairy sector is characterized by several typical products resulting from the links between product-territory, territory-breed/ species and breed/species-product. To avoid the possible substitution or the use of mixture of milk from different species, it is necessary to develop analytical procedures able to detect frauds and protect consumers from mislabeling (De La Fuente and Juárez, 2005; Mafra et al., 2007). In fact, the development of traceability systems can lead to the promotion of local and traditional cheeses (PDO and PGI), and thereby to the conservation and enhancement of the breeds of origin and/or local populations.

In the present work, a duplex-PCR method, to amplify $12 S$ and $16 S$ $r R N A$ gene fragments of mtDNA, was applied for molecular traceability of Sicilian mono-species dairy products.

\section{Materials and methods}

\subsection{Blood sampling and DNA extraction}

Sample collection, animal management and care followed the recommendation of EU Directive 2010/63/EU. A total of 300 individuals were sampled and $10 \mathrm{ml}$ of blood were collected from jugular vein through vacutainer tubes with EDTA as anticoagulant. We sampled animals from B. taurus, O. aries, and C. hircus species belonging to the most important Sicilian autochthonous breeds (Modicana and Cinisara cattle breeds, Comisana, Pinzirita and Valle del Belice sheep breeds, and Girgentana, Maltese and Derivata di Siria goat breeds). The individuals were collected from different farms located in Sicilian provinces. Genomic DNA was extracted from blood using a salting out method (Miller et al., 1988) and checked for quantity and quality by NanoDrop ND-1000 spectrophotometer (NanoDrop Technologies, Wilmington, DE, USA). All samples were diluted and stored at $4{ }^{\circ} \mathrm{C}$ until analysis.

\subsection{Simplex-PCR and mono-species DNA pools preparation}

In the first step, in order to check the specificity of primer pairs on each breed as tested by Bottero et al. (2003), a simplex-PCR protocol was applied on a total of 80 individual samples, 10 for each sampled breed in order to amplify $12 S$ and $16 S$ rRNA mitochondrial gene fragments using primers proposed by Bottero et al. (2003) (Table 1). In particular, both $12 S$ and $16 S$ rRNA gene fragments were amplified in $O$. aries species while only $12 S r R N A$ gene fragment was amplified in $B$. taurus and C. hircus species.

Table 1

Oligonucleotides used as PCR primer pairs for amplification of mitochondrial $12 S$ and $16 S$ gene fragments in Ovis aries, Bos taurus, and Capra hircus species.

\begin{tabular}{clc}
\hline Species and genes & Oligonucleotide primers & Amplicons \\
\hline Ovis aries (12S and & FW: 5'-ATATCAACCACACGAGAGGAGAC & \multirow{2}{*}{$172 \mathrm{bp}$} \\
16 ) & $-3^{\prime}$ & \\
(GenBank Acc. No. & RV: 5'-TAAACTGGAGAGTGGGAGAT-3' & \\
NC_001941) & & \multirow{2}{*}{$256 \mathrm{bp}$} \\
Bos taurus (12S) & FW: 5'-GTACTACTAGCAACAGCTTA-3' & \\
(GenBank Acc. No. & RV: 5'-GCTTGATTCTCTTGGTGTAGAG & \\
NC_006853) & $-33^{\prime}$ & $326 \mathrm{bp}$ \\
Capra hircus (12S) & FW: 5'-CGCCCTCCAAATCAATAAG-3' \\
(GenBank Acc. No. & RV: 5'-AGTGTATCAGCTGCAGTAGGGTT & \\
M55541) & $-3^{\prime}$ & \\
\hline
\end{tabular}

PCR amplifications were performed in a final volume of $25 \mu \mathrm{l}$ containing $1 \mu \mathrm{M}$ of each primer, $0.8 \mathrm{mM}$ of dNTP Mix, $1 \mathrm{U}$ of Taq DNA polymerase (Fermentas, Hanover, MD, USA), 1X PCR buffer with $\mathrm{KCl}$, $3 \mathrm{mM} \mathrm{MgCl}_{2}$, and approximately $100 \mathrm{ng}$ of genomic DNA. Thermal cycling conditions were an initial denaturation at $94^{\circ} \mathrm{C}$ for $5 \mathrm{~min}, 35$ cycles at $94{ }^{\circ} \mathrm{C}, 53{ }^{\circ} \mathrm{C}$ and $72{ }^{\circ} \mathrm{C}$ for $2 \mathrm{~min}$ and $30 \mathrm{~s}$ each, and a final extension at $72{ }^{\circ} \mathrm{C}$ for $5 \mathrm{~min}$. Amplified fragments were checked by electrophoresis on $2 \%$ agarose gel stained with ethidium bromide (Fig. 1A)..

For mono-species DNA pools preparation, samples were chosen after their positive amplification in simplex-PCR. In particular, 5 samples for each breed for each species were used. A total of $10 \mu \mathrm{l}$ of diluted DNA $(50 \mathrm{ng} / \mu \mathrm{l})$ of each sample were used to constitute the three different pools. To evaluate data repeatability and reproducibility, individual samples and mono-species DNA pools were amplified in triplicate and analyses were carried out independently by two experienced operators. The same simplex-PCR protocol was applied to monospecies DNA pools to confirm the length of expected fragments and amplification products were checked by electrophoresis on $2 \%$ agarose gel stained with ethidium bromide (Fig. 1B).

\subsection{Duplex-PCR and multi-species DNA pools preparation}

The second step involved the application of duplex-PCR protocol to detect, at the same time, each species present both in multi-species DNA pools and in reference experimental cheese samples. For duplexPCR protocol, some tests with DNA of mono-species pools were carried out in order to verify the real specificity of each species-specific primer pairs. Thermal cycling conditions were the same as simplex-PCR protocol.

After these preliminary analyses, multi-species DNA pools containing known mixtures of DNA from two species at the same time were prepared as reported in Table 2. In order to evaluate repeatability and reproducibility of data from multi-species DNA pools, these samples were amplified in triplicate and analyzed as reported above. Moreover, some tests were carried out in order to choose the better amplification condition and the optimal primers concentrations. Duplex-PCR amplifications were performed in a final volume of $30 \mu \mathrm{l}$ containing different concentration of each primers pair (from $0.5 \mu \mathrm{M}$ for mono-species DNA pools to $0.8 \mu \mathrm{M}$ for multi-species DNA pools), $0.8 \mathrm{mM}$ of dNTP Mix, $1 \mathrm{U}$ of Taq DNA polymerase (Fermentas, Hanover, MD, USA), $1 \mathrm{X}$ PCR buffer with $\mathrm{KCl}, 3.5 \mathrm{mM} \mathrm{MgCl}_{2}$, and approximately $200 \mathrm{ng}$ of genomic DNA. The amplification products were checked by electrophoresis on $2 \%$ agarose gel stained with ethidium bromide (Fig. 2). Optimized duplex-PCR protocol was applied to evaluate the visual detection limit of each mixture on $2 \%$ agarose gel..

\subsection{Reference cheeses samples and DNA extraction}

Reference experimental cheeses were prepared in a dairy facility in Belmonte Mezzagno (Palermo province, Sicily, Italy), using mixtures of cows', ewes' and goats' raw milk from Sicilian local dairy farms. Experimental cheeses were prepared according to the classical Sicilian cheese-making procedure from raw milk starting from mixture with known concentration of two different milks.

In particular, for cows' cheeses, three mixtures were prepared adding ewes' milk and other three mixtures adding goats' milk in the following percentages: $0.1 \%, 0.5 \%$, and $1 \%$ in cows' milk. The same six mixtures were prepared for ewes' cheeses adding separately cows' and goats' milk in ewes' milk, and for goats' cheeses adding cows' and ewes' milk in goats' milk.

For DNA extraction from cheeses the CTAB method of ISO 21571:2005(E) (International Organization for Standardization (ISO), 2005) was used, making some changes to the protocol for sample preparation (i.e. $5 \mathrm{~g}$ of cheese sample, use of proteinase $\mathrm{K}$, and incubation overnight at $50{ }^{\circ} \mathrm{C}$ ). Five samples from each cheese were 

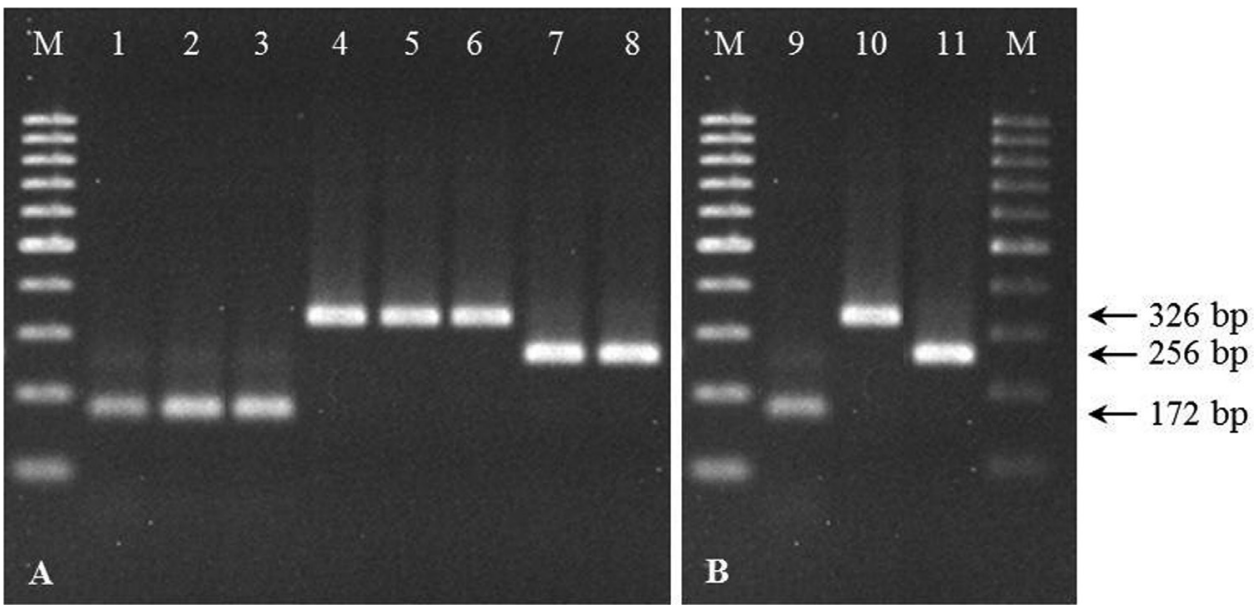

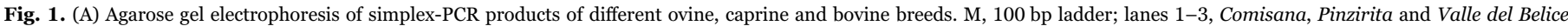

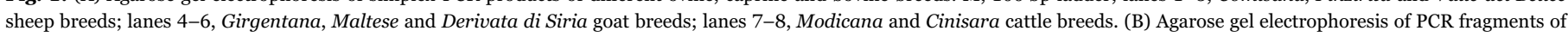
mono-species DNA pools from Ovis aries (lane 9), Bos taurus (lane 10), and Capra hircus (lane 11) species.

Table 2

Multi-species DNA pools containing different percentages (\%) of Bos taurus (B), Ovis aries (O), and Capra hircus (C) mixtures of DNA. Indications within brackets are referred to Fig. 2 (Ref. Fig. 2).

\begin{tabular}{lllllll}
\hline Ref.Fig. 2 & $\begin{array}{l}\mathrm{B}+\mathrm{O}(\%) \\
{[\mathbf{2 ~ A}]}\end{array}$ & $\begin{array}{l}\mathrm{O}+\mathrm{B}(\%) \\
{[\mathbf{2 B}]}\end{array}$ & $\begin{array}{l}\mathrm{B}+\mathrm{C}(\%) \\
{[\mathbf{2} \mathbf{C}]}\end{array}$ & $\begin{array}{l}\mathrm{C}+\mathrm{B}(\%) \\
{[\mathbf{2 D}]}\end{array}$ & $\begin{array}{l}\mathrm{O}+\mathrm{C}(\%) \\
{[\mathbf{2 E}]}\end{array}$ & $\begin{array}{l}\mathrm{C}+\mathrm{O}(\%) \\
{[\mathbf{2} \mathbf{~ F}]}\end{array}$ \\
\hline \multirow{2}{*}{ Lane 1 } & 50.0 & 50.0 & 50.0 & 50.0 & 50.0 & 50.0 \\
& +50.0 & +50.0 & +50.0 & +50.0 & +50.0 & +50.0 \\
Lane 2 & 75.0 & 75.0 & 75.0 & 75.0 & 75.0 & 75.0 \\
& +25.0 & +25.0 & +25.0 & +25.0 & +25.0 & +25.0 \\
Lane 3 & 90.0 & 90.0 & 90.0 & 90.0 & 90.0 & 90.0 \\
& +10.0 & +10.0 & +10.0 & +10.0 & +10.0 & +10.0 \\
Lane 4 & $99.5+0.5$ & $99.5+0.5$ & $99.5+0.5$ & $99.5+0.5$ & $99.5+0.5$ & $99.5+0.5$ \\
Lane 5 & $99.9+0.1$ & $99.9+0.1$ & $99.9+0.1$ & $99.9+0.1$ & $99.9+0.1$ & $99.9+0.1$ \\
\hline
\end{tabular}

collected for DNA extraction and used as technical and biological replicates. The concentration of extracted DNA was checked using NanoDrop ND-1000 spectrophotometer (NanoDrop Technologies, Wilmington, DE, USA) and samples were stored at $4{ }^{\circ} \mathrm{C}$ until use. Finally, duplex-PCR protocol was applied to experimentally cheese samples to evaluate the minimum (visual) threshold of each DNA mixture. Amplification products were checked on $2 \%$ agarose gel stained with ethidium bromide.

\section{Results and discussion}

Extracted DNA was used as a template to amplify species-specific fragments of mtDNA, $12 S$ and $16 S r R N A$, through primers sets proposed by Bottero et al. (2003) in order to assess their applicability to Sicilian autochthonous breeds and species. Previous works showed the application of different PCR protocols on different mitochondrial genes to differentiate cows', goats' and ewes' milk or cheeses by means of species-specific primers as reported by Guerriero et al. (2012).

Since Lipkin et al. (1993) showed the technical convenience of milk as a source of DNA, several PCR-based methods have been developed for authenticity assessment of dairy products, as reported by Mafra et al. (2008).

\subsection{Specificity of PCR protocol}

In the first part of our work, DNA extracted from cows', ewes', and goats' blood samples $(n=80)$ was used to verify the specificity of primer pairs proposed by Bottero et al. (2003). The optimized simplex-PCR protocol was applied on individual samples of each considered breed and subsequently on mono-species DNA pools in order to confirm the specific fragment lengths and $172 \mathrm{bp}, 256 \mathrm{bp}$ and $326 \mathrm{bp}$ for $O$. aries, B. taurus, and C. hircus species. Electrophoresis on agarose gels of PCR products showed good species-specific amplifications and perfect separation of the three expected fragments both in individual samples (Fig. 1A) and in mono-species DNA pools (Fig. 1B). These results were in agreement with those reported by other authors on different cows', ewes' and goats' breeds (Bottero et al., 2003; Mafra et al., 2004; Mafra et al., 2007) using the same primer pairs proposed by Bottero et al. (2003).

The next step involved the application of duplex-PCR protocols on mono-species DNA pools in order to verify the real specificity of each species-specific primer pairs and then the optimization of primers concentrations and amplification conditions on multi-species DNA pools. Good results of amplification were obtained for duplex-PCR protocols on multi-species DNA pools as showed in Fig. 2. PCR amplifications for individual samples, mono-species and multi-species DNA pools gave satisfactory results in terms of reproducibility and repeatability and this simplified the laboratory work and reduced the analyses costs.

\subsection{Sensitivity of PCR protocol}

Electrophoretic patterns of all duplex-PCR protocols applied on multi-species DNA pools from known mixtures reported in Table 2, are showed in Fig. 2. In particular, for all the multi-species DNA pools the visual detection threshold was $0.1 \%$. This means that $0.1 \%$ of ewes' DNA was found both in ewes'/cows' and ewes'/goats' DNA pools (Figs. 2A and F, lanes 5); $0.1 \%$ of goats' DNA was found both in goats'/cows' and goats'/ewes' DNA pools (Figs. 2C and E, lanes 5), and, finally, $0.1 \%$ of cows' DNA was found both in cows'/goats' and cows'/ ewes' DNA pools (Figs. 2D and B, lanes 5). Moreover, duplex-PCR protocols were tested on experimental cheeses to confirm the identified visual detection threshold of $0.1 \%$ in multi-species DNA pools. Fig. 3 showed good PCR amplifications for all reference experimental cheeses and confirmed the visual detection threshold of $0.1 \%$ of "contaminant" DNA from another species..

In particular, lanes 1 of Figs. 3A and B showed ewes' and goats' DNA fragments in cows' cheeses; lanes 1 of Figs. 3C and D showed cows' and goats' DNA fragments in ewes' cheeses; and, finally, lanes 1 of Figs. 3E and F showed cows' and ewes' DNA fragments in goats' experimental cheeses.

Our results are in agreement with previous studies in which detection threshold of $0.1 \%$ of cows' milk in ewes' and goats' cheeses (Mafra et al., 2007) is reported. Moreover, other authors (López-Calleja et al., 2004; Maudet and Taberlet, 2001) reported the same detection 

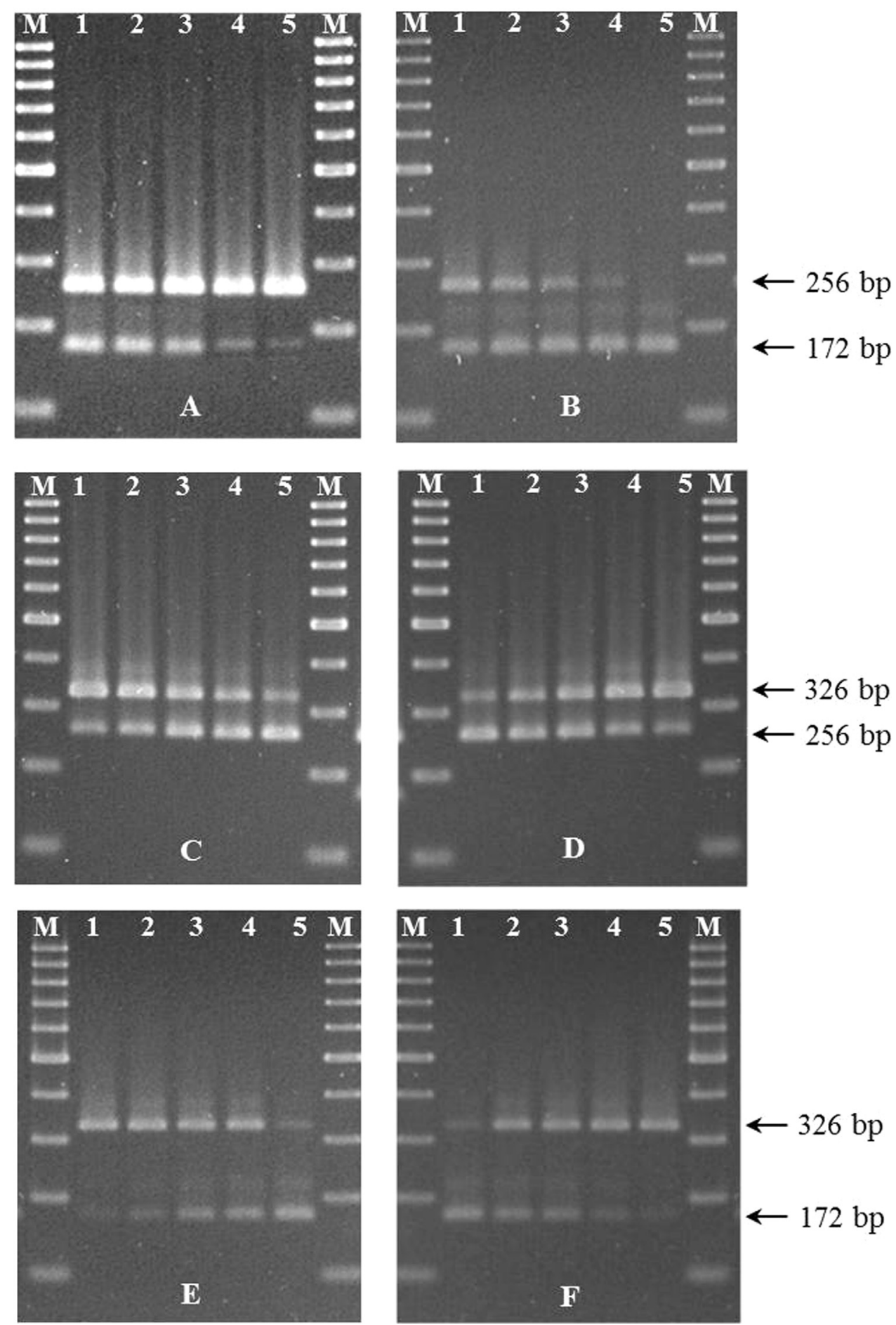

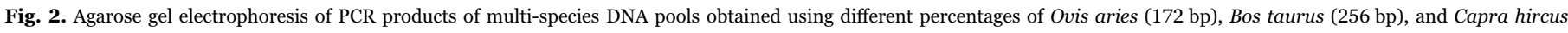
(356 bp) mixtures of DNA as reported in Table 2; M, 100 bp ladder.

threshold of $0.1 \%$ of cows' milk both in goats' cheeses (Maudet and Taberlet, 2001) and in ewes' and goats' milk (López-Calleja et al., 2004) using different primers targeting mitochondrial DNA control region and $12 S$ rRNA gene.

Our $0.1 \%$ detection thresholds were more precise than the ones reported by Bottero et al. (2003) which were only able to detect $0.5 \%$ of cow's milk in mixture of cows' and goats' milk using the same primers.

\section{Conclusions}

Nowadays, mitochondrial genome was successfully used by several authors as target to detect undeclared milk in dairy products thank to its several advantages over nuclear DNA as the abundance and the relatively high mutation rate to better define species differences.

The duplex-PCR protocols gave us satisfactory results in term of costs and time consuming. Therefore, it could be useful to use these protocols in species traceability system. Considering that typical Sicilian dairy products are important for economy and traditions, and for the conservation of livestock local populations, the ability to detect low levels of contaminating milk could be interesting to safeguard not only mono-species dairy products protected by European labels (PDO and PGI) but also allergic or intolerant subjects. 

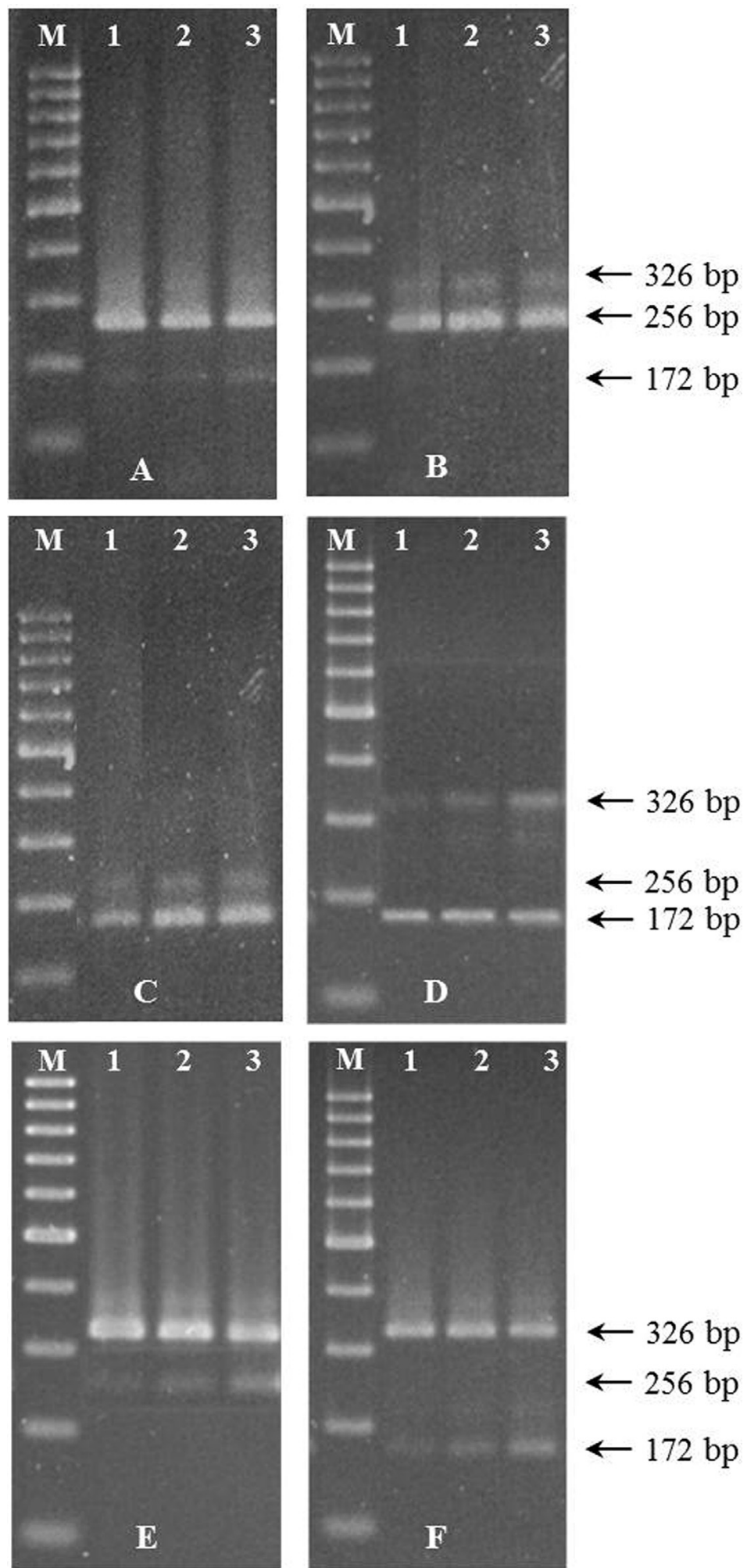

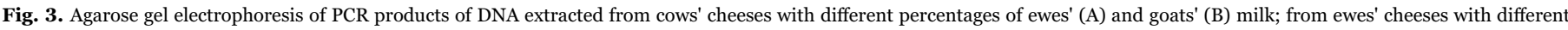

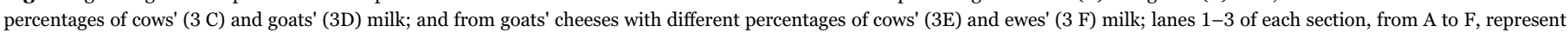
$0.1 \%, 0.5 \%$ and $1 \%$ of "contaminant" DNA in experimental cheeses; $\mathrm{M}, 100 \mathrm{bp}$ ladder.

\section{Conflict of interest}

The authors declare that they have no competing interests.

\section{Acknowledgement}

This research was financed by PON02_00451_3133441, CUP: B61C1200076005 funded by MIUR. 


\section{References}

Bánáti, D., Herman, O., 2011. Consumer response to food scandals and scares. Trends. Food Sci. Tech. 22, 56-60.

Bottero, M.T., Civera, T., Anastacio, A., Turi, R.M., Rosati, S., 2002. Identification of cow's milk in "buffalo" cheese by duplex polymerase chain reaction. J. Food Prot. 65, 362-366.

Bottero, M.T., Civera, T., Nucera, D., Rosati, S., Sacchi, P., Turi, R.M., 2003. A multiplex polymerase chain reaction for the identification of cows', goats' and sheep's milk in dairy products. Int. Dairy J. 13, 277-282.

Branciari, R., Nijman, I.J., Plas, M.E., Di Antonio, E., Lenstra, J.A., 2000. Species origin of milk in Italian mozzarella and greek feta cheese. J. Food Prot. 63, 408-411.

Chianese, L., Laezza, P., Smaldone, L.A., Stingo, C., Del Giovine, L., Addeo, F., 1990. Evaluation of bovine milk in the buffalo mozzarella cheese by two-dimensional electrophoresis. Sci. Tec. Latt. Cas. 41, 315-326.

Dalmasso, A., Civera, T., La Neve, F., Bottero, M.T., 2011. Simultaneus detection of cow and buffalo milk in mozzarella cheese by Real-Time PCR assay. Food Chem. 124, $362-366$.

De La Fuente, M.A., Juárez, M., 2005. Authenticity assessment of dairy products. Crit. Rev. Food Sci. Nutr. 45, 563-585.

De Noni, I., Tirelli, A., Masotti, F., 1996. Determinazione del latte di vacca nei formaggi di specie minori: applicazione ai formaggi di capra. Sci. Tec. Latt. Cas. 47, 7-17.

Enne, G., Elez, D., Fondrini, F., Bonizzi, I., Feligini, M., Aleandri, R., 2005. Highperformance liquid chromatography of governing liquid to detect illegal bovine milk addition in water buffalo Mozzarella: comparison with results from raw milk and cheese matrix. J. Chromatogr. A 1094, 169-178.

European Commission, 2008. Commission Regulation (EC) No 273/2008 of 5 March 2008 laying down detailed rules for the application of Council Regulation (EC) No $1255 / 1999$ as regards methods for the analysis and quality evaluation of milk and milk products. Off. J. Eur. Comm. L88, 1-115.

Feligini, M., Bonizzi, I., Curik, V., Parma, P., Greppi, G.F., Enne, G., 2005. Detection of adulteration in Italian Mozzarella cheese using mitochondrial DNA templates as biomarkers. Food Technol. Biotech. 43, 91-95.

Fernández, A., Fabuel, E., Alves, E., Rodriguez, C., Silió, L., Óvilo, C., 2004. DNA tests based on coat colour genes for authentication of the raw material of meat products from Iberian pigs. J. Sci. Food Agr. 84, 1855-1860.

Galimberti, A., De Mattia, F., Losa, A., Bruni, I., Federici, S., Casiraghi, M., Martellos, S., Labra, M., 2013. DNA barcoding as a new tool for food traceability. Food Res. Int. $50,55-63$

Guerriero, J.S., Fernandes, P., Bardsley, R.G., 2012. Identification of the species of origin of milk in cheeses by multivariate statistical analysis of polymerase chain reaction electrophoretic patterns. Int. Dairy J. 25, 42-45.

Hurley, I.P., Coleman, R.C., Ireland, H.E., Williams, J.H.H., 2004. Measurement of bovine IgG by indirect competitive ELISA as a means of detecting milk adulteration. J. Dairy Sci. 87, 543-549.

Lipkin, E., Shalom, A., Khatib, H., Soller, M., Friedmann, A., 1993. Milk as a source of deoxyribonucleic acid and as a substrate for the polymerase chain reaction. J. Dairy
Sci. 76, 2025-2032.

López-Calleja, I., González, A., Fajardo, V., Rodríguez, M.A., Hernández, P.E., García, T., Martin, R., 2005a. PCR detection of cows' milk in water buffalo milk and mozzarella cheese. Int. Dairy J. 15, 1122-1129.

López-Calleja, I., González, I., Fajardo, V., Martín, I., Hernández, P.E., García, T., Martín, R., 2005b. Application of polymerase chain reaction to detect adulteration of sheep's milk with goats' milk. J. Dairy Sci. 88, 3115-3120.

López-Calleja, I., González, I., Fajardo, V., Hernández, P.E., García, T., Martín, R., 2007a. Application of an indirect ELISA and a PCR technique for detection of cows' milk in sheep's and goats' milk cheeses. Int. Dairy J. 17, 87-93.

López-Calleja, I., González, I., Fajardo, V., Martín, I., Hernández, P.E., García, T., Martín, R., 2007b. Quantitative detection of goats' milk in sheep's milk by realtime PCR. Food Control 18, 1466-1473.

López-Calleja, I., González, I., Fajardo, V., Martín, I., Hernández, P.E., García, T., Martín, R., 2007c. Real-time TaqMan PCR for quantitative detection of cows' milk in ewes' milk mixtures. Int. Dairy J. 17, 729-736.

López-Calleja, I., González, I., Fajardo, V., Rodríguez, M.A., Hernández, P.E., García, T., Martín, R., 2004. Rapid detection of cows' milk in sheeps' and goats' milk by a species-specific polymerase chain reaction technique. J. Dairy Sci. 87, 2839-2845.

Mafra, I., Ferreira, I.M., Oliveira, B.P., 2008. Food authentication by PCR-based methods. Eur. Food Res. Technol. 227, pp. 649-665.

Mafra, I., Ferreira, I.M., Faria, M.A., Oliveira, B.P., 2004. A novel approach to the quantification of bovine milk in ovine cheeses using a duplex polymerase chain reaction method. J. Agric. Food Chem. 52, 4943-4947.

Mafra, I., Roxo, A., Ferreira, I.M., Oliveira, B.P., 2007. A duplex polymerase chain reaction for the quantitative detection of cows' milk in goats' milk cheese. Int. Dairy J. 17, 1132-1138.

Maudet, C., Taberlet, P., 2001. Detection of cows' milk in goats' cheeses inferred from mitochondrial DNA polymorphism. J. Dairy Res. 68, 229-235.

Mayer, H.K., 2005. Milk species identification in cheese varieties using electrophoretic, chromatographic and PCR techniques. Int. Dairy J. 15, 595-604.

McKean, J.D., 2001. The importance of traceability for public health and consumer protection. Rev. Sci. Tech. OIE 20, 363-378.

Miller, S.A., Dykes, D.D., Polesky, H.F., 1988. A simple salting out procedure for extracting DNA from human nucleated cells. Nucl. Acids Res. 16, 1215.

Molina, E., Martín-Álvarez, P.J., Ramos, M., 1999. Analysis of cows', ewes' and goats' milk mixtures by capillary electrophoresis: quantification by multivariate regression analysis. Int. Dairy J. 9, 99-105.

Nicolaou, N., Xu, Y., Goodacre, R., 2011. MALDI-MS and multivariate analysis for the detection and quantification of different milk species. Anal. Bioanal. Chem. 399, 3491-3502.

Plath, A., Krause, I., Einspanier, R., 1997. Species identification in dairy products by three different DNA-based techniques. Z. Leb. Unters Forsch. A 205, 437-441.

Xue, H., Hu, W., Son, H., Han, Y., Yang, Z., 2010. Indirect ELISA for detection and quantification of bovine milk in goat milk. Food Sci. 31, 370-373.

Zeleňáková, L., Golian, J., Zajác, P., 2008. Application of ELISA tests for detection of milk and cheese adulteration. Milchwissenschaft 63, 137-141. 